\title{
Keberlanjutan Penerapan Teknologi Pengelolaan Pekarangan oleh Wanita Tani di Kabupaten Kuningan
}

\section{Application of the Sustainability of Backyard Utilization Technology by Farmer's Wives in Kuningan District}

\author{
Ani Suryani ${ }^{1}$, Anna Fatchiya ${ }^{2}$, Djoko Susanto ${ }^{3}$ \\ ${ }^{1}$ Balai Pengkajian Teknologi Pertanian Jawa Barat, Lembang \\ 2,3 Departemen Sains Komunikasi dan Pengembangan Masyarakat, Institut Pertanian Bogor, Bogor
}

\begin{abstract}
Application of backyard utilization technology sustainability by farmer's wive was basically intended to respond the issue of national food security, food availability versus population growth, land conversion issue and the importance of food diversification awareness. This study was aimed: (1) to analyze individual characteristics, the characteristics of innovation, facilitators' performance, external support and sustainability of the application of backyard utilization technology; (2) to analyze the effects of individual characteristics, the characteristics of innovation, facilitators' performance, and external support on the sustainability of backyard utilization technology. The study was carried out in the sub-district of Sindangagung and Jalaksana, Kuningan district, West Java province. The sample included 76 farmer's wives.The important results used multiple regression analysis F-test (simultaneously), all independent variables i.e.individual characteristics, the characteristics of innovation, educator's/facilitator's perfomance and support from the external environment that have significant effects on adopting the sustainability. Its effect was $72,4 \%$ while the remaining $27,6 \%$ was influenced by other variables outside the model.The indicator variables i.e. individual characteristics that had significant influence were age, motivation, number of dependents, level of education, the time to manage and family income. Indicators of innovation characteristics were the relative advantages and suitability level of innovation. Performance indicator of facilitators were the frequency and knowledge level of facilitator. All indicators of external marketing support, family support, groupsupport and infrastructuresupporthave significant effects on adopting the sustainability of backyard management.
\end{abstract}

Keywords: Adoption, backyard, farmer's wives, sustainability

\begin{abstract}
Abstrak
Keberlanjutan penerapan teknologi pengelolaan pekarangan oleh wanita tani pada dasarnya ditujukan guna menghadapi isu ketahanan pangan nasional, perbandingan ketersediaan pangan vs pertambahan jumlah penduduk, isu alih fungsi lahan dan kesadaran tentang pentingnya upaya diversifikasi pangan. Penelitian ini bertujuan: (1) menganalisis karakteristik individu, karakteristik inovasi, kinerja fasilitator, dukungan eksternal dan keberlanjutan penerapan teknologi pengelolaan pekarangan; (2) mengkaji pengaruh karakteristik individu, karakteristik inovasi, kinerja fasilitator, dan dukungan eksternal terhadap keberlanjutan penerapan teknologi pengelolaan pekarangan. Penelitian dilakukan di Kecamatan Sindangagung dan Kecamatan Jalaksana, Kabupaten Kuningan Provinsi Jawa Barat. Sampel penelitian berjumlah 76 orang wanita tani. Hasil analisis regresi linear berganda Uji F (simultan), semua peubah bebas karakteristik individu, karakteristik inovasi, kinerja penyuluh/fasilitator dan dukungan lingkungan eksternal memiliki pengaruh nyata terhadap keberlanjutan adopsi. Nilai pengaruh sebesar $72,4 \%$ sedangkan sisanya 27,6\% dipengaruhi oleh peubah lain yang tidak ada di dalam model regresi. Secara berurutan indikator peubah karakteristik individu yang berpengaruh nyata adalah umur, motivasi, jumlah anggota keluarga, tingkat pendidikan, curahan waktu wanita tani dan pendapatan keluarga. Indikator karakteristik inovasi adalah keuntungan relatif dan tingkat kesesuaian inovasi. Indikator kinerja fasilitator adalah tingkat kunjungan dan tingkat pengetahuan. Semua indikator dukungan eksternal pemasaran, dukungan keluarga, dukungan kelompok dan sarana prasarana berpengaruh nyata terhadap keberlanjutan pengelolaan lahan pekarangan.
\end{abstract}

Kata kunci: Adopsi, lahan pekarangan, wanita tani, keberlanjutan

\section{Pendahuluan}

Keberlanjutan dari penerapan teknologi pengelolaan pekarangan oleh wanita tani pada dasarnya ditujukan guna menghadapi isu ketahanan pangan nasional, perbandingan ketersediaan pangan versus pertambahan jumlah penduduk, isu alih fungsi lahan dan kesadaran tentang pentingnya upaya diversifikasi pangan. Pengelolaan lahan pekarangan yang berkelanjutan pada hakekatnya merupakan 
suatu perilaku dari individu pelaksana kegiatan agar tetap melaksanakan kegiatan pengelolaan lahan pekarangan pasca program. Melanjutkan kegiatan pengelolaan lahan pekarangan pasca program merupakan salah satu potensi dan strategi untuk mewujudkan kemandirian pangan di tingkat rumahtangga.

Program-program pengelolaan pekarangan umumnya ditujukan sebagai program pemberdayaan masyarakat terutama kaum wanita tani dalam pemenuhan pangan dan gizi keluarga dan membantu menambah pendapatan rumah tangga. Peran ini menciptakan keuntungan ganda karena di satu sisi wanita tani dapat memenuhi kebutuhan pangan dan gizi keluarga dan ikut membantu meringankan beban keluarganya serta menambah pendapatan keluarga. Dalam empat tahun terakhir pemerintah kembali mengembangkan program pengelolaan lahan pekarangan yang dilakukan oleh Kementerian Pertanian dengan menyusun suatu konsep Kawasan Rumah Pangan Lestari (KRPL). Berdasarkan hasil pengamatan Badan Litbang Pertanian, pengetahuan masyarakat terhadap teknologi pengelolaan lahan pekarangan relatif masih terbatas, sehingga pengembangan berbagai inovasi yang terkait dengan lahan pekarangan belum banyak berkembang sebagaimana yang diharapkan. Selain inovasi, pengembangan pengelolaan lahan pekarangan perlu didukung oleh kualitas sumberdaya manusia wanita tani, bimbingan dan pendampingan fasilitator dan dukungan eksternal lainnya sehingga lebih memungkinkan keberlanjutan penerapan teknologi di masyarakat.Sejalan dengan Purnaningsih et al., (2006); Indrianingsih (2010) keputusan petani dalam berusaha tani ditentukan oleh keunggulan ekonomi komoditas dan interaksi antara pelaku yang berkepentingan dalam proses adopsi inovasi. Oleh sebab itu, pengelolaan pekarangan dapat dilaksanakan dengan sungguh-sungguh dan memerlukan dukungan dari berbagai pihak. Keputusan anggota kelompok wanita tani dalam melanjutkan atau tidak melanjutkan kegiatan pengelolaan pekarangan juga diduga dipengaruhi oleh dukungan eksternal.

Keberlanjutan kegiatan pengelolaan pekarangan pasca program sangat dibutuhkan seiring dengan jumlah penduduk yang terus mengalami peningkatan yang menyebabkan kebutuhan bahan pangan semakin bertambah. Dengan melaksanakan kegiatan pengelolaan pekarangan untuk tanaman pangan, tanaman obat, hortikultura berpotensi dapat memenuhi kebutuhan pangan keluarga. Pengelolaan pekarangan juga berpeluang menambah penghasilan rumah tangga apabila dirancang dan direncanakan dengan baik serta dapat menjaga kelestarian lingkungan (Mardiharini, 2011). Walaupun berbagai upaya program telah dilakukan pemerintah, namun pada kenyataannya tingkat konsumsi gizi masyarakat masih rendah, masyarakat masih bertumpu pada pangan utama beras. Hal itu diindikasikan oleh skor Pola Pangan Harapan (PPH) yang belum sesuai harapan, dan belum optimalnya pemanfaatan sumber bahan pangan lokal dalam mendukung penganekaragaman konsumsi pangan (BKP, 2010).

Pengelolaan pekarangan secara berkelanjutan dapat dilaksanakan dengan baik apabila didukung oleh karakteristik individu wanita tani yang baik, karakteristik inovasi teknologi yang dikembangkan, bimbingan fasilitator dan dukungan sarana prasarana penerapan teknologi. Berdasarkan hal tersebut, penelitian ini bertujuan untuk mengukur tingkat keberlanjutan penerapan teknologi pengelolaan pekarangan oleh wanita tani dan mengkaji faktorfaktor yang berpengaruh terhadap keberlanjutan penerapan teknologi pengelolaan pekarangan oleh wanita tani di Kabupaten Kuningan.

\section{MetodePenelitian}

Penelitian ini didesain secara kuantitatif dan kualitatif (Mixed method), dengan menggunakan metode survey. Penelitian dilakukan di Kecamatan Sindangagungdan Kecamatan JalaksanaKabupaten Kuningan. Penelitian dilaksanakan dari Bulan April sampai Agustus 2016. Responden penelitian adalah wanita tani yang telah menerapkan dan masih menerapkan teknologi pengelolaan pekarangan, berjumlah 76 responden. Untuk wawancara mendalam dipilih secara sengaja pengurus dan anggota kelompok wanita tani dari dua lokasi penelitian. Data primer diperoleh melalui wawancara terstruktur, wawancara mendalam, dan observasi di lapangan. Data sekunder dikumpulkan dari lembaga terkait melalui teknik studi literatur (desk study). Datayang terkumpul kemudian ditabulasi dan dianalisis secara deskriptif. Untuk melihat pengaruh antar peubah dilakukan uji regresi linier berganda dengan menggunakan SPSS 16. 


\section{Hasil dan Pembahasan}

\section{Tingkat Keberlanjutan Adopsi Inovasi Teknologi Pengelolaan Pekarangan}

Salah satu isu penting dalam pengembangan inovasi teknologi pengelolaan pekarangan di masyarakat adalah dengan melihat aspek keberlanjutan (sustainability) inovasi teknologi tersebut.Keberlanjutan pengelolaan pekarangan merupakan konfirmasi dari anggota kelompok wanita tani dalam melanjutkan atau tidak kegiatan pengelolaan pekarangan. Keberlanjutan pengelolaan pekarangan ditandai dengan keberlanjutan produksi, keberlanjutan kemitraan dan keberlanjutan ekonomi. Keberlanjutan ekonomi di lakukan dengan melihat hasil analisis usaha pekarangan yang dilakukan dengan menghitung pemasukan, pengeluaran, serta keuntungan dari lahan yang dikelola wanita tani pada saat penelitian. Tingkat keberlanjutan usaha lahan pekarangan ditentukan dengan analisis Revenue/ Cost Ratio ( $\mathrm{R} / \mathrm{C}$ ratio).

Keberlanjutan secara produksi dinilai dari tingkat penerapan (adopsi) teknologi pengelolaan pekarangan secara kumulatif yang dikonversi dalam besaran persentase tingkat penerapan. Semakin tinggi tingkat penerapan teknologi pengelolaan pekarangan, maka dipandang kegiatan berlanjut. Diukur berdasarkan jumlah komponen teknologi yang diterapkan dan jumlah frekuensi penanaman. Sedangkan keberlanjutan kemitraan dinilai dari banyaknya kerjasama kegiatan yang dilakukan wanita tani.

Tabel 1 menunjukkan bahwa tingkat keberlanjutan adopsi inovasi pengelolaan pekarangan secara berurutan ditunjukkan dengan keberlanjutan ekonomi, keberlanjutan produksi dan keberlanjutan kemitraan. Artinya, peluang keberlanjutan adopsi inovasi teknologi pengelolaan pekarangan terus berlanjut karena didukung secara ekonomi menguntungkan, secara keberlanjutan produksi masih dilaksanakan dan masih dilakukannya kemitraan antara wanita tani dengan pihak luar.

Keberlanjutan Produksi. Pengelolaan pekarangan di Kabupaten Kuningan dilakukan dengan tiga model penanaman yaitu penanaman secara konvensional, penanaman dengan menggunakan pot dan penanaman secara vertikultur. Penanaman konvensional dilakukan dengan menanam langsung di tanah dan prinsipnya sama dengan berkebun sayuran dalam arti sebenarnya, tetapi skalanya lebih kecil sesuai dengan lahan yang tersedia.Penanaman dengan menggunakan pot dilakukandalam pot-pot tanaman sebagai pilihan untuk lebih memperbanyak jumlah tanaman dan jenis sayuran yangdiusahakan. Penanaman secara vertikultur yang dilakukan menggunakan wadah tanam vertikal untuk mengatasi keterbatasan lahan seperti media paralon, bambu dan lain sebagainya. Pemilihan ketiga model penanaman tersebut, bergantung pada jenis tanaman yang ditanam dan disesuaikan dengan minat para wanita tanidengan memperhatikan faktor luas pekarangan, iklim dan manfaat dari tanaman yang dihasilkan.

Pengenalan teknologi berupa pengelolaan pekarangan di kedua lokasi penelitian disampaikan melalui pelatihan teori, pertemuan kelompok, dan demplot. Cara pembelajaran teknologi dalam kegiatan pengelolaan pekarangan dilakukan dalam beberapatahapan kegiatan yakni sosialisasi, pelatihan teori di kelas, diskusi dalam pertemuankelompok dan pembelajaran langsung melalui demplot yang memerlukan waktu rata-rata tigabulan. Sosialisasi dilakukan melalui media LCD yang disertai dengan gambar-gambar yang berkenaan denganpengelolaan pekarangan yang sudah berhasil.Denganlangsung melihat contoh melalui gambar peserta mendapat gambaran bagaimana model yangakan dikembangkan dan hasil yang akan dicapai melalui kegiatan ini.

Setelah peserta memperoleh gambaran secara lebih rinci dalam bentuk teori,tahap berikutnya adalah mempraktekkan teori tahapdemi tahap. Misalnya pada praktekpenyemaian, fasilitator memberikan contoh langsung lalu memberiinstruksi tahap demitahap agar wanita tanimempraktekkannya.Praktek ini dilakukan secara bersama dikebundemplot. Pada materi pembuatanKebun Bibit Desa (KBD) diperdalam melaluipertemuan kelompok. Dalam pertemuan kelompok fasilitator memberikan sedikit pengarahan lalu memandu wanita tani mempraktekannya. Acara pertemuan kelompok dilakukan di ruang terbuka atau didalamruangan dan dirancang suasana santai penuh keakraban. Pada pertemuan ini seringdilakukan diskusi tanya jawab antara peneliti/ penyuluh dengan wanita tani. Dalam kegiatan pengelolaan pekarangan di Kabupaten Kuningan, 
Jurnal Penyuluhan, Maret 2017 Vol. 13 No. 1

Tabel 1. Persentase Tingkat Keberlanjutan Adopsi Pengelolaan Pekarangan

\begin{tabular}{|c|c|c|c|c|c|c|c|}
\hline \multirow{2}{*}{$\begin{array}{c}\text { Keberlanjutan Penerapan } \\
\text { Teknologi }\end{array}$} & \multirow[t]{2}{*}{ Kriteria } & \multicolumn{2}{|c|}{$\begin{array}{c}\text { Kecamatan } \\
\text { Sindangagung }\end{array}$} & \multicolumn{2}{|c|}{$\begin{array}{c}\text { Kecamatan } \\
\text { Jalaksana }\end{array}$} & \multicolumn{2}{|c|}{ Total } \\
\hline & & $\mathbf{N}$ & $\%$ & $\mathbf{N}$ & $\%$ & $\mathbf{N}$ & $\%$ \\
\hline Keberlanjutan produksi & Sangat rendah & 0 & 0,00 & 0 & 0,00 & 0 & 0,00 \\
\hline Selang skor (2-4) & Rendah & 16 & 40,00 & 7 & 19,44 & 23 & 30,26 \\
\hline Rataan $=2,73$ & Tinggi & 23 & 57,50 & 28 & 77,78 & 51 & 67,11 \\
\hline \multirow{2}{*}{$\mathrm{STDEV}=0,505$} & Sangat tinggi & 1 & 2,50 & 1 & 2,78 & 2 & 2,63 \\
\hline & Jumlah & 40 & 100,00 & 36 & 100,00 & 76 & 100,00 \\
\hline Keberlanjutan kemitraan & Sangat rendah & 9 & 22,50 & 0 & 0,00 & 9 & 11,84 \\
\hline Selang skor (1-3) & Rendah & 25 & 62,50 & 21 & 58,33 & 46 & 60,53 \\
\hline Rataan $=2,41$ & Tinggi & 6 & 15,00 & 15 & 41,67 & 21 & 27,63 \\
\hline \multirow[t]{2}{*}{$\mathrm{STDEV}=0,604$} & Sangat tinggi & 0 & 0,00 & 0 & 0,00 & 0 & 0,00 \\
\hline & Jumlah & 40 & 100,00 & 36 & 100,00 & 76 & 100,00 \\
\hline Keberlanjutan ekonomi & Sangat rendah & 7 & 17,50 & 6 & 16,67 & 13 & 17,11 \\
\hline Selang skor (22.500-462.500) & Rendah & 9 & 22,50 & 1 & 2,78 & 10 & 13,16 \\
\hline Rataan $=304.901$ & Tinggi & 8 & 20,00 & 5 & 13,89 & 13 & 17,11 \\
\hline \multirow[t]{2}{*}{$\mathrm{STDEV}=133.202$} & Sangat tinggi & 16 & 40,00 & 24 & 66,67 & 40 & 52,63 \\
\hline & Jumlah & 40 & 100,00 & 36 & 100,00 & 76 & 100,00 \\
\hline
\end{tabular}

rata-rata pertemuan rutin kelompok dilakukan dua kali dalam sebulan.Pertemuan kelompok dilakukan cukup intensifsehingga kedekatan penyuluh/peneliti tercipta. Anggota KWT selanjutnya diberi tanggung jawabuntuk mengelola kebun demplot dan kebun bibit secara bersama.Metode pembelajaranyang intensif ini diharapkan dapat diadopsi oleh wanita tani.

Pelaksanaan penerapan teknologi di Kecamatan Sindangagung (wilayah dataran rendah) diikuti dengan tuntas oleh seluruh wanita tani hingga akhir bimbingan. Selama pelaksanaan, seluruh wanita tani antusias mengikuti kegiatan. Pada waktu awal pembinaan (Tahun 2012) terdapat 40 peserta (wanita tani), dan tahun berikutnya (2013) bertambah hingga $250 \%$, menjadi 140 wanita tani, dan pada akhir Tahun 2014 menjadi 220 wanita tani yang menerapkan teknologi pengelolaan pekarangan. Saat melakukan penelitian (Tahun 2016) anggota yang tercatat masih aktif melakukankegiatan pengelolaan pekarangan sebanyak 120 wanita tani.Keaktifan mereka dalam melakukan kegiatan mengelola lahan disebabkan KWT yang aktif. Kelompok dengan anggota ada hubungankekerabatan, dan terbiasa bekerja keras bersama. Mereka mengelola secara bersama kebun demplotuntuk bertanam aneka sayuran dan memperoleh hasil untuk kebutuhan anggota dansebagian mereka jual. Terbukti dengan diperolehnya juara satupada Tahun 2013 dalam lomba pengelolaan pekarangan tingkat nasional.

Kegiatan pengelolaan pekarangan pada tahun kedua (2013) merupakan model pengembagan implementasi yang dilakukan di Kecamatan Jalaksana (wilayah dataran tinggi). Di Kecamatan Jalaksana diadopsi model inovasi teknologi pengelolaan pekarangan, namun keberadaan BPTP tidak se-intensif di Kecamatan Sindangagung. Pihak pemerintah daerah dan kelompok yang lebih sering melakukan pembinaan di lapangan. Hingga saat penelitian ini dilakukan, terdapat sekitar 100 wanita tani yang masih menerapkan teknologi pengelolaan pekarangan (dari 40 wanita tani pada awal kegiatan). Perhatian pemerintah daerah dan peran besar para pengurus KWT dan gapoktan,menjadikan kemajuan berkembangnya jumlah wanita tani yang mengelola pekarangan.

Pekarangan di Kabupaten Kuningan memiliki potensi yang cukup luas untuk dikembangkan, baik dilihat dari luas maupun untuk memproduksi aneka ragam pangan dalam penyediaan bahan pangan yang bergizi bagi keluarga. Hampir semua wanita tani yang menjadi responden penelitian ini membudidayakan tanaman jenis sayuran sebagai produk utama usaha pekarangan mereka. Namun, ada sebagian kecil wanita tani yang juga membudidayakan usaha lain selain tanaman sayuran seperti ikan dan ternak. Jadi, wanita tani dapat menikmati hasil panen selain dari tanaman sayuran juga dapat memperoleh dari hasil 
ternak. Hal ini terlihat dari besarnya jumlah dan persentase responden yang tidak mengusahakan ternak di lahan mereka. Di Kecamatan Sindangagung, pengusahaan ternak (utamanya unggas dan ikan) sebanyak $20 \%$ responden ternak unggas dan di bawah 5\% pengusahaan ikan. Di Kecamatan Jalaksana sebanyak $11 \%$ responden mengusahakan ternak dan sekitar $10 \%$ yang mengusahakan budidaya ikan (Tabel 2).

Dalam perkembangannya saat penelitian (Tabel 2), terlihat bahwa penerapan teknologi pengelolaan pekarangan masih berjalan dengan baik. Hal ini diindikasikan dengan masih berjalannya kegiatan Kebun Bibit Desa (KBD) di kedua lokasi penelitian. KBD merupakan salah satu pilar utama pelaksanaan kegiatan pengelolaan pekarangan, karena KBD mensuplai benih dan bibit para anggotanya. Sekitar 97,5\% responden di Kecamatan Sindangagung dan seluruh responden di Kecamatan Jalaksana membuktikan bahwa pelaksanaan pengelolaan pekarangan masih berjalan. Implementasi inovasi seperti pembuatan media tanam, pembuatan persemaian benih, pembumbunan bibit, pembuatan dan penataaan tanaman, cara penanaman ramah lingkungan masih terus diadopsi oleh responden (92,5\%).Di kedua lokasi penelitian inovasi pembuatan kompos/pupuk organik dan pembuatan pestisida nabati persentasenya menurun. Hal ini disebabkan oleh ketersediaan bahan baku yang semakin berkurang, dan harga bahan pembuatan kompos dan pestisida nabati dirasakan cukup mahal bagi sebagian anggota. Responden mengungkapkan bahwa pembuatan kompos/pupuk organik dan pembuatan pestisida nabati dirasakan tidak efektif apabila dilakukan oleh masing-masing individu. Ketidakefektifan tersebut dalam hal biaya dan waktu pembuatan. Jadi sebaiknya pembuatan kompos organik dan pestisida nabati dilakukan

Tabel 2. Persentase Beberapa Indikator Adopsi Inovasi Teknologi Pengelolaan Pekarangan

\begin{tabular}{|c|c|c|c|c|c|c|}
\hline \multirow{2}{*}{ Tingkat keberlanjutan } & \multicolumn{3}{|c|}{ Kec. Sindangagung } & \multicolumn{3}{|c|}{ Kec. Jalaksana } \\
\hline & Menerapkan & Tidak & Frekuensi & Menerapkan & Tidak & Frekuensi \\
\hline \multicolumn{7}{|l|}{ Keberlanjutan Produksi : } \\
\hline $\begin{array}{l}\text { - } \begin{array}{l}\text { Pembuatan Kebun Bibit Desa } \\
\text { (KBD) }\end{array}\end{array}$ & 97,5 & 2,5 & 1 & 100,0 & 0,0 & 1 \\
\hline $\begin{array}{l}\text { Pembuatan media tanam untuk } \\
\text { pertanaman }\end{array}$ & 100,0 & 0,0 & 4 & 100,0 & 0,0 & 3 \\
\hline - Persemaian benih & 92,5 & 7,5 & 2 & 100,0 & 0,0 & 3 \\
\hline - Pembumbunan bibit & 97,5 & 2,5 & 5 & 100,0 & 0,0 & 3 \\
\hline $\begin{array}{l}\text { - Pembuatan dan penataan jenis/ } \\
\text { tempat penanaman }\end{array}$ & 100,0 & 0,0 & 3 & 97,2 & 2,8 & 7 \\
\hline $\begin{array}{l}\text { - Cara penanaman sayuran, buah } \\
\text { dan obat }\end{array}$ & 100,0 & 0,0 & 3 & 94,4 & 5,6 & 2 \\
\hline $\begin{array}{l}\text { - Cara perawatan tanaman ramah } \\
\text { lingkungan }\end{array}$ & 100,0 & 0,0 & 6 & 100,0 & 0,0 & 2 \\
\hline - Pembuatan kompos/pupuk organik & 60,0 & 40,0 & 2 & 69,4 & 30,6 & 1 \\
\hline - Pembuatan pestisida nabati & 35,0 & 65,0 & 1 & 52,8 & 47,2 & 1 \\
\hline - Pembuatan kandang ternak & 2,5 & 97,5 & 1 & 19,4 & 80,6 & 1 \\
\hline - $\quad$ Budidaya ternak kecil (kambing) & 0,0 & 100,0 & - & 13,9 & 86,1 & 1 \\
\hline $\begin{array}{l}\text { Budidaya ternak unggas (ayam, } \\
\text { bebek, dll.) }\end{array}$ & 20,0 & 80,0 & 3 & 11,1 & 88,9 & 3 \\
\hline - Pembuatan kolam ikan alas plastik & 5,0 & 95,0 & 1 & 8,3 & 91,7 & 1 \\
\hline $\begin{array}{l}\text { - Pembibitan ikan pada kolam alas } \\
\text { plastik }\end{array}$ & 2,5 & 97,5 & 1 & 5,6 & 94,4 & 1 \\
\hline $\begin{array}{l}\text { - Budidaya ikan pada kolam alas } \\
\text { plastik }\end{array}$ & 5,0 & 95,0 & 7 & 8,3 & 91,7 & 1 \\
\hline $\begin{array}{l}\text { - Model penataan halaman berbagai } \\
\text { strata luasan }\end{array}$ & 100,0 & 0,0 & 1 & 97,2 & 2,8 & 1 \\
\hline
\end{tabular}

Sumber: data primer 2016 
oleh kelompok dan didistribusikan ke anggota. Berdasarkan hasil pengamatan, kepemilikan hewan ternak ternyata sangat mempengaruhi praktek pertanian organik di kedua lokasi penelitian. Terbukti bahwa hampir semua wanita tani yang memiliki hewan ternak, memanfaatkannya sebagai pupuk organik.

Tingkat adopsi lainnya yang mengalami penurunan adalah inovasi pengelolaan budidaya ikan dan ternak. Budidaya ikan yang dipraktekkan dilahan pekarangan dan demplot umumnyamenghasilkan panen yang cukup baik. Namun karena memerlukan modal cukup besaruntuk membeli bibit dan pakan hanya beberapa orang saja yang melaksanakan budidaya ikan. Hal ini disebabkan, tidak semua tipe pekarangan dapat menerapkan teknologi budidaya ikan dan ternak.

Keberlanjutan Kemitraan. Kerjasama dengan pihak ketiga (pihak mitra kerjasama) sangat penting dilakukan guna pengembangan dan keberlanjutan kegiatan program.Apalagi untuk usaha lahan pekarangan yang merupakan usaha produk sampingan keluarga. Telah dilakukan kerjasama kemitraan yang mencakup kemitraan pemasaran, kemitraan input sarana produksi dan kemitraan dalam hal informasi. Kemitraan pemasaran dilakukan individu maupun kelompok sebagai jembatan mitra.

Saat ini kemitraan bidang pemasaran usaha lahan pekarangan di lakukan dengan beberapa pedagang pengumpul, pedagang sayuran, pedagang bakso dan beberapa kelompok di luar wilayah. Pada pelaksanaannya, bentuk kemitraan tidak tertuang dalam satu bentuk perjanjian tertulis, namun berdasarkan ikatan kepercayaan antara kedua belah pihak. Hal tersebut berlaku karena masih terbatasnya jumlah produksi usaha lahan pekarangan dan kelangsungan produksi yang belum terjamin. Saat ini, pemasaran produk dilakukan melalui penjualan langsung kepada pengecer. Upaya promosi produk terus dilakukan, baik melalui kelompok di luar wilayah, konsumen langsung individu maupun perusahan seperti dengan pondok pesantren, rumah sakit dan lainnya.

Tabel 3 menunjukkan bahwa di Kecamatan Sindangagung $77,5 \%$ responden tidak bermitra. Hasil produksi sebagian besar untuk konsumsi, sebanyak $22,5 \%$ hasil produksi dijual ke konsumen langsung. Berbeda halnya dengan wanita tanidi
Tabel 3. Persentase Keberlanjutan Kemitraan

\begin{tabular}{|c|c|c|c|}
\hline No. & $\begin{array}{c}\text { Keberlanjutan } \\
\text { Kemitraan }\end{array}$ & $\begin{array}{c}\text { Kec. } \\
\text { Sindangagung } \\
(\%) \\
\end{array}$ & $\begin{array}{c}\text { Kec. } \\
\text { Jalaksana } \\
(\%) \\
\end{array}$ \\
\hline \multirow[t]{7}{*}{1.} & Keberlanjutan & & \\
\hline & Mitra Pemasaran & & \\
\hline & $\begin{array}{ll}\text { - } & \text { Tidak ada } \\
& \text { mitra }\end{array}$ & 77,50 & 0,00 \\
\hline & 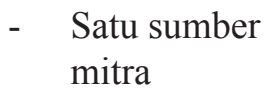 & 17,50 & 16,70 \\
\hline & $\begin{array}{l}\text { Dua sumber } \\
\text { mitra }\end{array}$ & 0,00 & 69,40 \\
\hline & 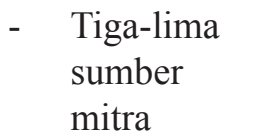 & 5,00 & 13,90 \\
\hline & Jumlah & 100,00 & 100,00 \\
\hline \multirow[t]{8}{*}{2.} & Keberlanjutan & & \\
\hline & Mitra Sarana & & \\
\hline & Produksi & & \\
\hline & $\begin{array}{l}\text { - } \quad \text { Tidak ada } \\
\text { mitra }\end{array}$ & 0,00 & 0,00 \\
\hline & 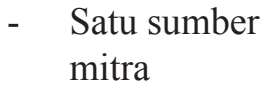 & 85,00 & 63,90 \\
\hline & $\begin{array}{l}\text { - Dua sumber } \\
\text { mitra }\end{array}$ & 15,00 & 36,10 \\
\hline & 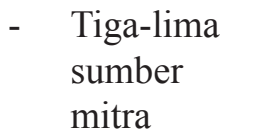 & 0,00 & 0,00 \\
\hline & Jumlah & 100,00 & 100,00 \\
\hline \multirow[t]{6}{*}{3.} & $\begin{array}{l}\text { Keberlanjutan } \\
\text { Mitra Informasi }\end{array}$ & & \\
\hline & - $\quad$ Satu mitra & 27,50 & 55,60 \\
\hline & $\begin{array}{l}\text { - Dua sumber } \\
\text { mitra }\end{array}$ & 5,00 & 19,40 \\
\hline & 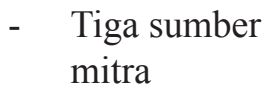 & 40,00 & 25,00 \\
\hline & $\begin{array}{ll}- & >\text { Tiga } \\
\text { sumber } \\
\text { mitra }\end{array}$ & 27,50 & 0,00 \\
\hline & Jumlah & 100,00 & 100,00 \\
\hline
\end{tabular}

Kecamatan Jalaksana, seluruh responden dapat menjual hasil sisa usaha lahan pekarangannya. Bagi wanita tanidi Kecamatan Jalaksana, pemasaran produk hasil pertanian dapat berjalan lancar. Mereka dapat menjual hasil produknya dengan mudah ke konsumen. Di Kecamatan Jalaksana sekitar 83\% responden telah bermitra dua hingga lebih mitra seperti pihak konsumen langsung, pondok pesantren, rumahsakit dan para pedagang pengumpul dan pedagang sayuran yang ada di wilayah Kecamatan 
Jalaksana.

Selain aspek pemasaran, mitra juga dilakukan dengan beberapa sumber sarana produksi seperti UnitPengelolaan Organik (UPO), gapoktan, KWT, kios, formulator dan lain-lain. Wanita tani yang mengelola pekarangannya, rata-rata menggunakan dua jenis pupuk untuk mencukupi kebutuhan usahatani lahan pekarangannya. Pupuk tersebut, yaitu: pupuk an-organik dan sebagianwanita tanimenggunakan pupuk organik. Di Kecamatan Sindangagung kebutuhan pupuk organik telah disediakan oleh UPO (dana pembuatan UPO dan penyediaan ternak sapi dari Dinas Pertanian Peternakan dan Perikanan Kabupaten Kuningan pada Tahun Anggaran 2011), yang dikelola oleh gapoktan. UPO tersebut saat ini telah menghasilkan pupuk organik (bokashi), pupuk cair, pupuk hijau, dan pengembangan bakteri melalui proses fermentasi. Wanita tani/KWT tinggal membelinya di UPO tersebut, bahkan pupuk organik hasil dari UPO Kecamatan Sindangagung pemasarannya sudah meluas ke kecamatan-kecamatan yang lain, salah satunya adalah Kecamatan Jalaksana. Di Kecamatan Jalaksana dan lokasi yang menerapkan teknologi pengelolaan pekarangan, rata-rata memperoleh pupuk organik dari UPO Kecamatan Sindangagung. Penggunaan pupuk non organik oleh wanita tani perlahan-lahan mulai dikurangi, seperti: Urea, SP-36, KCl, dan lain-lain untuk mendorong dipraktekkannya pertanian organik di pekarangan.

Beberapa produk inovatif yang khas memiliki nilai jual tinggi di pasaran seperti Brukoli, Brungkol/ Kembang Kol, Cabe Besar (Lembang 1), Selada Ungu, Kubis Merah, Paria Ular dan lain sebagainya. Komoditas-komoditas tersebut sebelumnya belum pernah diusahakan oleh responden, namun setelah terjalin hubungan dengan sumber informasi maka komoditas-komoditas tersebut menjadi komoditi unggulan lahan pekarangan. Berdasarkan informasi responden, sumber mitra informasi teknologi selain KWT dan gapoktan terdapat juga BPTP Jawa Barat dan Petugas Penyuluh Lapangan (PPL) dari dinas terkait. Tabel 3 menunjukkan bahwa semua responden di kedua lokasi penelitian memiliki mitra informasi lebih dari dua sumber. Pada perkembangan era informasi digital seperti sekarang, informasi dapat dengan mudah ditransfer dan diperolehwanita tani.

Keberlanjutan Ekonomi. Aspek ekonomi dilihat dari bidang pertanian, dapat dikatakan berlanjut bila produksi pertanian mampu mencukupi kebutuhan pangan, dan memberikan pendapatan yang layak untuk melaksanakan keberlanjutan penghidupan, khususnya bagi para wanita tani. Menurut Ho dan Ching (2006), pertanian menjamin keberlanjutan ekonomi yang terlihat dari pertanian dapat meningkatkan ketahanan pangan dan keuntungan bagi masyarakat lokal selain baik juga untuk kesehatan gizi keluarga.

Hasil panen responden adalah sayuran dalam bentuk segar. Penggunaan hasil produksi usaha lahan pekarangan digunakan untuk konsumsi keluarga, dijual, atau keduanya. Kebutuhan keluarga akan pangan bergizi sangat penting, sehingga penggunaan hasil panen untuk konsumsi keluarga tidak mungkin dihindari dan menjadi suatu keharusan. Responden yang menggunakan hasil panen untuk konsumsi keluarganya sendiri, belum tentu menjual hasil panen tersebut kepada konsumen atau pasar. Sebaliknya, petani yang menjual hasil panennya kepada konsumen atau pasar, sudah pasti menyisakan sebagian hasil panennya untuk dikonsumsi keluarganya sendiri. Oleh karena itu, penggunaan hasil panen oleh responden yang ditampilkan dalam Tabel 4, meliputi penggunaan untuk dijual.

Tabel 4 memperlihatkan analisis usahatani lahan pekarangan dilakukan pada masing-masing komoditas utama yang biasa diusahakan di dua lokasi penelitian untuk mengetahui sampai sejauh mana keuntungan usahatani lahan pekarangan. Peubah sistem usaha lahan pekarangan yang dianalisis dalam penelitian ini, antara lain: tingkat output atau produktivitas usaha pekarangan per musim; keuntungan usahatani per musim yang diketahui melalui hasil pengurangan penerimaan usahatani per musim dengan biaya input produksi usahatani per musim. Semua peubah di atas merupakan peubah yang mudah diukur untuk mengetahui keberlanjutan ekonomi responden dilihat dari sistem usahataninya. Penulis menggunakan asumsi harga yang berlaku saat penelitian untuk mempermudah analisis finansial pada masing-masing sistem usaha lahan pekarangan dalam satu musim. Selain itu, responden juga tidak dapat mengingat biaya input produksi usahataninya secara rinci maupun harga hasil panen mereka per kilogram.Jenis tanaman budidaya dalam usahatani lahan pekarangan yang dianalisis dalam 
Jurnal Penyuluhan, Maret 2017 Vol. 13 No. 1

Tabel 4. Total Produksi, Penerimaan dan Keuntungan Usaha Lahan Pekarangan Per-Musim

\begin{tabular}{llrrrrrc}
\hline No. & Jenis komoditas & $\begin{array}{c}\text { Total } \\
\text { produksi (kg) }\end{array}$ & $\begin{array}{c}\text { Harga } \\
\text { (Rp.) }\end{array}$ & $\begin{array}{c}\text { Penerimaan } \\
\text { (Rp.) }\end{array}$ & $\begin{array}{c}\text { Biaya } \\
\text { (Rp.) }\end{array}$ & $\begin{array}{c}\text { Keuntungan } \\
\text { (Rp.) }\end{array}$ & $\begin{array}{c}\text { R/C } \\
\text { Rasio }\end{array}$ \\
\hline 1 & Strowberi & 6 & $10.000,-$ & $60.000,-$ & $30.000,-$ & $30.000,-$ & 2,0 \\
2 & Cabe Besar & 30 & $10.000,-$ & $300.000,-$ & $60.000,-$ & $240.000,-$ & 5,0 \\
3 & Sosin & 10 & $2.000,-$ & $20.000,-$ & $5.000,-$ & $15.000,-$ & 4,0 \\
4 & Seledri & 20 & $10.000,-$ & $200.000,-$ & $100.000,-$ & $100.000,-$ & 2,0 \\
5 & Brunkol & 3 & $10.000,-$ & $30.000,-$ & $10.000,-$ & $20.000,-$ & 3,0 \\
6 & Cabe Cengek & 6 & $20.000,-$ & $120.000,-$ & $20.000,-$ & $100.000,-$ & 6,0 \\
7 & Terung & 6 & $10.000,-$ & $60.000,-$ & $20.000,-$ & $40.000,-$ & 3,0 \\
8 & B. Daun & 2 & $12.500,-$ & $25.000,-$ & $5.000,-$ & $20.000,-$ & 5,0 \\
9 & Kubis & 3 & $10.000,-$ & $30.000,-$ & $10.000,-$ & $20.000,-$ & 3,0 \\
\hline
\end{tabular}

Sumber: data primer 2016

penelitian ini adalah sembilan komoditas utama. Untuk mengetahui lebih jelas mengenai rata-rata tingkat input dan output usahatani lahan pekarangan sembilan komoditas utama permusim, berikut disajikan Tabel 4.

Analisis finansial usahatani lahan pekarangan dilakukan untuk mengetahui lebih jelas mengenai biaya input produksi, penerimaan usahatani, keuntungan dan nilai R/C Rasio per musim. Analisis finansial ini akan menjawab sampai sejauhmana pengaruh praktik pertanian lahan pekarangan terhadap keberlanjutan ekonomi rumahtangga petani. Perhitungan finansial pada masing-masing kategori, seperti: biaya input produksi, penerimaan usahatani dan keuntungan merupakan nilai ratarata dari semua responden. Berdasarkan Tabel 4, terlihat bahwa usahatani lahan pekarangan dengan 9 komoditas yang dikembangkan layak untuk dilanjutkan, hal ini terlihat dari nilai $\mathrm{R} / \mathrm{C}$ Ratio $\geq 2$. Sebagian besar wanita tani tidak hanya melihat manfaat pertanian pekarangan dari sisi produktivitas yang dibandingkan dengan pertanian biasa, tetapi juga dari sisi nilai tambah pendapatan keluarga. Selain itu, biaya input operasional pertanian pekarangan dinilai lebih rendah daripada pertanian konvensional (lahan). Keuntungan pengelolaan pekarangan terhadap bidang ekonomi antara lain: (1) meningkatnya pendapatan rumahtangga;(2) terciptanya lapangan kerja baru; dan (3) meningkatnya daya saing dan nilai tambah produk agribisnis. Usahatani di pekarangan jika dikelola secara intensif sesuai dengan potensi pekarangan, di samping dapat memenuhi kebutuhan konsumsi rumah tangga, juga dapat memberikan sumbangan pendapatan bagi keluarga.

Usahatani lahan pekarangan merupakan kegiatan yang positif bagi wanita taniselain ramah lingkungan juga dapat memenuhi kebutuhan gizi keluarganya.Hasil dari pengelolaan pekarangan sebagian besar dimanfaatkan petani untuk memenuhi kebutuhan konsumsi keluarga sehingga mengurangi beban pengeluaran untuk belanja konsumsi sayursayuran sehari-hari, namun ada juga responden yang sebagian hasil panennya dikonsumsi dan lebihnya dijual kepada pedagang terdekat dengan rumah mereka. Bagi wanita tani yang menjual hasil usahataninya, mereka menjual ke warung-warung terdekat rumah atau pedagang pengumpul yang menjemput ke lahan mereka untuk dijual ke pasar.

Wanita tani memperoleh penghasilan tambahan dari usahatani lahan pekarangan di Kecamatan Sindangagung untuk dua komoditas yang diusahakan sebesar Rp. 42.500,- s/d 340.000,- lebih besar dibandingkan pengusahaan dua komoditas di Kecamatan Jalaksana (Tabel 5). Pengusahaan terbesar di dua kecamatan didominasi oleh pengusahaan usahatani lebih dari empat komoditas. Di Kecamatan Sindangagung terdapat $62,5 \%$ dan di Kecamatan Jalaksana sebesar $69,4 \%$ dengan ratarata keuntungan yang diperoleh antara Rp. 107.500,s/d 462.500,-. Nilai tersebut merupakan nilai dari jumlah produksi yang dijual ke konsumen. Namun terdapat manfaat tidak tunai. Manfaat tidak tunai artinya hasil panen dari usahatani lahan pekarangan tidak hanya berupa uang dan jika diuangkan akan sejumlah nominal yang diuraikan di atas. Manfaat tidak tunai tersebut adalah hasil usahatani lahan pekarangan lebih besar dimanfaatkan petani untuk 
Tabel 5. Persentase Jumlah Komoditas dan Besaran Nilai Keuntungan

\begin{tabular}{lcccc}
\hline \multirow{2}{*}{ Jumlah komoditas } & \multicolumn{2}{c}{ Kecamatan Sindangagung } & \multicolumn{2}{c}{ Kecamatan Jalaksana } \\
\cline { 2 - 5 } & $\mathbf{\%}$ & Keuntungan (Rp.) & $\mathbf{\%}$ & Keuntungan (Rp.) \\
\hline Satu komoditas & 5,0 & 22.500 & - & - \\
Dua komoditas & 12,5 & $42.500-340.000$ & 11,1 & $42.500-122.500$ \\
Tiga komoditas & 20,0 & $162.500-380.000$ & 19,4 & $80.000-370.000$ \\
$\geq$ empat komoditas & 62,5 & $107.500-410.000$ & 69,4 & $157.500-462.500$ \\
\hline
\end{tabular}

Sumber: data primer 2016

kebutuhan konsumsi sehari-hari rumah tangga sehingga dapat menekan pengeluaran belanja. Ratarata pendapatan yang merupakan manfaat tidak tunai adalah berkisar Rp.65.780,-hingga \pm Rp.80.000,- Artinya dari hasil panen usahatani, wanita tani tidak lagi membeli sayuran untuk konsumsi rumah tangga sehari-hari untuk beberapa hari ke depan dan pengeluaran yang seharusnya digunakan untuk belanja kebutuhan dapat ditabung untuk keperluan lainnya seperti kebutuhan sekolah anak dan belanja lainnya. Manfaat lain dari adanya pengelolaan pekarangan adalah kegiatan ini untuk menambah pendapatan dan mengisi kegiatan yang positif dengan berusahatani, menciptakan keterampilan baru dalam bercocok tanam bagi petani serta dapat memperindah pekarangan rumah dan memenuhi gizi keluarga.

Hasil analisis penelitian menunjukkan rata-rata pendapatan petani dalam melaksanakan usahatani lahan pekarangan masih relatif kecil. Peningkatan pendapatan wanita tani dalam melaksanakan pengelolaan pekarangan tidak besar sehingga perubahan atau penambahan pada pendapatan rumah tangga petani juga tidak terlalu besar. Hal ini disebabkan umumnya wanita tanimemiliki pekarangan sempit $\left(>100 \mathrm{~m}^{2}\right)$ hingga sedang (100-300 $\mathrm{m}^{2}$ ), dan lahan belum dimanfaatkan secara optimal serta wanita tani tidak mempunyai keterampilan dan pengalaman budidaya yang mendalam sehingga mempengaruhi hasil produksi usahatani.

Kontribusi pendapatan dari usahatani lahan pekarangan terhadap pendapatan rumah tangga, telah memberikan kontribusi yang cukup membantu pendapatan rumah tangga petani. Mencermati harga-harga kebutuhan konsumsi sehari-hari yang mahal di Kabupaten Kuningan dan harga beberapa komoditi sayuran meningkat, wanita tani merasakan dapat memberikan kontribusi dalam meningkatkan pendapatan keluarga dan menekan pengeluaran konsumsi makanan sehari-hari. Keadaan tersebut dinyatakan oleh keseluruhan wanita tani sehingga wanita tani memanfaatkan lahan pekarangan mereka untuk berusahatani yang dibantu oleh fasilitator.

Perhitungan yang telah dilakukan diperoleh hasil sebagai berikut: (1) rata-rata pendapatan petani dari usahatani lahan pekarangan per bulan adalah Rp.86.250,-;(2) rata-rata pendapatan rumah tangga petani di luar usahatani lahan pekarangan adalah Rp.1.954.444,-; dan (3) rata-rata total pendapatan rumah tangga petani setelah adanya usahatani lahan pekarangan per bulan adalah Rp.2.040.694,-Agar dapat mengetahui besarnya kontribusi rata-rata pendapatan petani dalam menjalankan usahatani lahan pekarangan terhadap peningkatan pendapatan rumah tangga, maka digunakan rumus menurut Suratiyah (2003). Sehingga didapat ratarata kontribusi pendapatan yang diberikan petani terhadap pendapatan rumah tangga dalam mengelola pekarangan adalah sebagai berikut:

Pendapatan usaha lahan pekarangan (Rp.86.250,-)

Kontribusi $=$ Pendapatan keluarga $\times 100 \%$ (Rp.1.954.444,-)

Dilihat dari masing-masing kontribusi yang telah diberikan KWT dari pengelolaan pekarangan, hasil penelitian menujukkan rata-rata kontribusi yang telah disumbangkan petani lahan pekarangan terhadap ekonomi rumah tangga petani per bulan adalah 4,41\%. Walaupun kontribusinya tidak besar, namun kegiatan usahatani lahan pekarangan dirasakan wanita tani berperan cukup penting dalam menambah pendapatan rumah tangga dan telah memberi manfaat baik secara ekonomi maupun sosial. Komoditas pekarangan menjadi sarana sosialisasi dengan tetangga sekitar.Ketika responden memanen hasil pekarangannya, mereka berbagi antar tetangga dan saling bersilaturahmi bahkan 
tidak jarang wanita tani saling bertukar informasi tentang usahatani yang mereka lakukan.

\section{Faktor-faktor yang Berpengaruh terhadap Keberlanjutan Adopsi}

Rogers(2003)mengemukakanlimafungsiatau tahapan proses pengambilan keputusan inovasi, antara lain: (1) pengenalan (knowledge);(2) pembentukan sikap (persuasion); (3) pengambilan keputusan (decision); (4) pelaksanaan (implementation); dan (5) penegasan (confirmation). Proses pengambilan keputusan inovasi dipengaruhi oleh beberapa peubahbebasyang terdiri dari: (1) karakteristik individu; (2) karakteristik sosial ekonomi; dan (3) kekuatan penerimaan akan kebutuhan inovasi. Semua peubahbebas tersebut mempengaruhi kelangsungan setiap tahapan proses pengambilan keputusan inovasi. Suatu inovasi akan diadopsi atau ditolak, tergantung dari keputusan masing-masing individu sasaran inovasi.

Proses pengambilan keputusan inovasi sebagaimana yang dijelaskan oleh Mugniesyah (2006), dipengaruhi oleh persepsi unit pengambil keputusan inovasi terhadap karakteristik atau ciri-ciri inovasi. Karakteristik atau ciri-ciriinovasi tersebut, antara lain: (1) keuntungan relatif (relative advantage); (2) kesesuaian (compatibility); (3) kerumitan (complexity); (4) kemungkinan dicoba (trialability); dan (5) kemungkinan diamati (observability).

Meneliti gambaran faktor-faktor yang berhubungan terhadap keberlanjutan penerapan teknologi pengelolaan pekarangan maka dapat diketahui dan ditingkatkan faktor-faktor yang mempunyai pengaruh positif terhadap keberlangsungan penerapan inovasi dalam pengelolaan pekarangan.Dalam penelitian ini, analisis pengaruh antar faktor-faktor peubah penelitian mencakup empat peubah bebas yang meliputi: karakteristik individu, karakteristik inovasi, kinerja penyuluh/fasilitator dan dukungan lingkungan eksternal. Keempat peubah bebas tersebut mempunyai keterkaitan satu sama lain dan berpengaruh terhadap keberlanjutan penerapan teknologi pengelolaan pekarangan yang dilakukan wanita tani di Kecamatan Sindangagung dan Kecamatan Jalaksana, Kabupaten Kuningan.

Uji kelayakan model atau uji F (uji simultan model), model yang dibangun berdasarkan ke empat peubah bebas karakteristik individu, karakteristik inovasi, kinerja penyuluh/fasilitator dan dukungan lingkungan eksternal yang diestimasi dikatakan layak. Artinya, model yang diestimasi layak digunakan untuk menjelaskan pengaruh peubah-peubahbebas terhadap peubah terikat $\mathrm{Y}$ (Keberlanjutan adopsi). Persamaan regresi yang diperoleh dari peubah bebas terhadap keberlanjutan adopsi inovasi teknologi pengelolaan pekarangan yaitu:

$$
\begin{aligned}
\mathrm{Y}= & -5,875+0,716 \mathrm{X}_{1.1}+0,298 \mathrm{X}_{1.2}+0,341 \mathrm{X}_{1.3}+ \\
& 0,327 \mathrm{X}_{1.4}+0,190 \mathrm{X}_{1.5}+0,276 \mathrm{X}_{1.6}+0,211 \mathrm{X}_{2.1}+ \\
& 0,202 \mathrm{X}_{2.2}-0,297 \mathrm{X}_{2.3}+0,451 \mathrm{X}_{3.1}+0,426 \mathrm{X}_{3.3}+ \\
& 0,241 \mathrm{X}_{4.1}+0,198 \mathrm{X}_{4.2}+0,187 \mathrm{X}_{4.3}+0,400 \mathrm{X}_{4.4}
\end{aligned}
$$

Hasil analisis regresi berganda faktorfaktor yang mempengaruhi tingkat keberlanjutan adopsi wanita tani dalam menerapkan teknologi pengelolaan pekarangan ditunjukkan dengannilai koefisien determinasi. Nilai koeefisien determinasi menunjukkan bahwa terdapat variasi pengaruh peubah-peubah bebas karakteristik individu, karakteristik inovasi, kinerja penyuluh/fasilitator dan dukungan lingkungan eksternal terhadap peubah terikat keberlanjutan.

Besarnya nilai Rsquare 0,724 menunjukkan bahwa proporsi pengaruh peubah-peubah bebas sebesar 72,4\%. Artinya, karakteristik individu, karakteristik inovasi, kinerja penyuluh/fasilitator dan dukungan lingkungan eksternal memiliki proporsi pengaruh terhadap keberlanjutan adopsi sebesar $72,4 \%$ sedangkan sisanya $27,6 \%$ dipengaruhi oleh peubah lain yang tidak ada di dalam model regresi.

Melalui uji t (Tabel 6), menunjukkan pengaruh peubah bebas secara sendiri-sendiri (parsial) terhadap peubah terikat keberlanjutan adopsi. Uji signifikansi t yaitu uji yang digunakan untuk menilai pengaruh peubah-peubah bebas karakteristik individu, karakteristik inovasi, kinerja penyuluh/fasilitator dan dukungan lingkungan eksternal secara parsial berpengaruh terhadap peubah terikat keberlanjutan adopsi. Pada Tabel 5 dapat dilihat bahwa seluruh indikator karakteristik individu berpengaruh terhadap keberlanjutan adopsi. Secara berurutan indikator peubah karakteristik individu yang berpengaruh nyata adalah seperti umur $\left(\mathrm{t}_{\text {hit }} 4,79>1,96\right)$, motivasi $\left(\mathrm{t}_{\text {hit }} 4,31>1,96\right)$, jumlah anggota keluarga $\left(t_{\text {hit }} 4,12>1,96\right)$, tingkat pendidikan $\left(\mathrm{t}_{\text {hit }} 3,80>1,96\right)$, curahan waktu wanita 
$\operatorname{tani}\left(\mathrm{t}_{\text {hit }}, 26>1,96\right)$ dan pendapatan keluarga $\left(\mathrm{t}_{\text {hit }}, 2,33\right.$ $>1,96)$.

Umur merupakan salah satu faktor yang berhubungan nyata dengan wanita tani dalam keberlanjutan pengelolaan pekarangan. Semakin tua umur wanita tani maka curahan waktu untuk mengelola lahan pekarangan menjadi semakin tersedia. Kondisi berbeda jika umur muda di mana curahan waktu di luar (banyaknya kesibukan) menjadikan pekarangan rumah tidak dapat terkelola dengan baik. Responden yang berumur tua memberikan pendapat bahwa mereka melaksanakan kegiatan pengelolaan pekarangan karena kesenangan dan kebiasaan, selain itu karena anak-anak mereka sudah besar dan sudah memiliki keluarga masingmasing, sehingga waktu untuk mengurus anak dialihkan pada kegiatan pekarangan. Sejalan dengan Soekartawi (1988) yang mengatakan bahwa difusi inovasi yang paling tinggi adalah pada mereka yang berumur tua.

Terdapat pengaruh positif pendidikan terhadap keberlanjutan pengelolaan pekarangan. Hal iniberarti bahwa semakin tinggi pendidikan maka pengelolaan pekarangan semakin berlanjut. Pendidikan merupakan salah satu faktor yang berhubungan dengan wanita tani dalam keberlanjutan pengelolaan pekarangan. Tingkat pendidikan pada umumnya mempengaruhi cara dan pola berfikir wanita tani atau kemampuan pengetahuan dalam pengambilan keputusan. Sedikit sekali wanita tani responden yang mempunyai tingkat pendidikan sampai dengan jenjang universitas sehingga semakin lambat responden dalam pengambilan keputusan melanjutkan adopsi. Namun demikian, berdasarkan pengamatan lapang meskipun pendidikan formal responden relatif rendah, tetapi kegiatan pengelolaan pekarangan dapat terus berlanjut. Hal ini disebabkan adanya persepsi dari responden bahwa kegiatan pengelolaan pekarangan tidaklah sulit dilakukan, mereka dapat dengan mudah melaksanakannya. Bagi mereka, asalkan membawa manfaat dan kebaikan, maka pengelolaan lahan pekarangan akan terus mereka lakukan.

Motivasi wanita tani dalam pengelolaan pekarangan merupakan salah satu faktor peubah karakteristik yang mempengaruhi keberlanjutan adopsi. Motivasi guna memenuhi kebutuhan pangan dan gizi keluarga sehari-hari, memperoleh penghasilan tambahan keluarga dan menjalankan fungsi estetika lingkungan pekarangan merupakan motivasi yang menjadikan penyebab keberlanjutan pengelolaan lahan pekarangan. Berdasarkan hasil wawancara dengan responden, motif utama mengelola lahan pekarangan adalah untuk memenuhi kebutuhan pangan keluarga dan menambah pendapatan keluarga. Motif tersebut wajar mengingat responden adalah seorang wanita tani yang berhubungan dengan perannya dalam mengurus keluarga, menjaga keluarga, menyediakan makanan yang bergizi bagi keluarganya.

Curahan waktu berpengaruh nyata terhadap keberlanjutan pengelolaan lahan pekarangan (Tabel 6). Artinya, responden yang memiliki waktu cukup cenderung terus melaksanakan kegiatan pengelolaan pekarangan. Dengan adanya waktu untuk mengelola pekarangan, maka pekarangan terpelihara dengan baik, akan tercapai segala tujuan pengelolaan pekarangan tersebut. Kisaran waktu responden dalam melaksanakan pengelolaan pekarangan adalah dua sampai dengan tiga jam per hari. Waktu tersebut dirasakan cukup karena kegiatan pengelolaan pekarangan merupakan kegiatan menanam tanaman di sekitar rumah yang dapat dilakukan kapan saja mulai dari pagi hingga sore, artinya responden tidak terlalu membutuhkan waktu khusus untuk memanfaatkan lahan pekarangan, kecuali pada tahap-tahap tertentu seperti pada saat memulai kegiatan usaha pekarangan.

Pendapatan keluarga merupakan salah satu faktoryangmempengaruhikeberlanjutanpengelolaan pekarangan. Bagi keluarga yang berpenghasilan rendah, pengelolaan pekarangan menjadi penting artinya untuk memperoleh pendapatan keluarga. Responden yang berpendapatan rendah mengarah pada tanaman yang tersedia secara lokal, memanfaatkan sumberdaya yang ada di lingkungan, serta saling tolong-menolong dalam memperoleh sarana produksi dengan anggota lainnya, sehingga jenis tanaman lebih bervariasi. Kondisi berbeda jika pendapatan keluarga tinggi, pengelolaan pekarangan untuk dijadikan lahan usahatani pekarangan peluangnya semakin kecil. Kecenderungan jika satu keluarga telah cukup bahkan berlebih pendapatan, maka pengelolaan pekarangan diarahkan lebih kepada unsur estetika/keindahan dengan tanamantanaman hias. Mereka lebih akan membeli kebutuhan pangannya daripada mengusahakan. Kalaupun terdapat responden dengan pendapatan yang tinggi 
Tabel 6. Faktor-faktor yang Berpengaruh terhadap Keberlanjutan Pengelolaan Pekarangan

\begin{tabular}{|c|c|c|}
\hline No. & Peubah/indikator & $\begin{array}{c}\text { Keberlanjutan penerapan } \\
\text { teknologi pengelolaan } \\
\text { pekarangan (t) }\end{array}$ \\
\hline 1 & Umur & $4,793^{*}$ \\
\hline 2 & Tingkat pendidikan & $3,805^{*}$ \\
\hline 3 & $\begin{array}{l}\text { Jumlah anggota } \\
\text { keluarga }\end{array}$ & $4,120 *$ \\
\hline 4 & Motivasi & $4,310 *$ \\
\hline 5 & $\begin{array}{l}\text { Pendapatan } \\
\text { keluarga }\end{array}$ & $2,331 *$ \\
\hline 6 & Curahan waktu & $3,258^{*}$ \\
\hline 7 & Keuntungan relatif & $2,413 *$ \\
\hline 8 & Kesesuaian & $2,303 *$ \\
\hline 9 & Kerumitan & $-3,518^{*}$ \\
\hline 10 & Dapat diuji coba & $-1,845$ \\
\hline 11 & Dapat diamati & 1,336 \\
\hline 12 & $\begin{array}{l}\text { Frekuensi } \\
\text { kunjungan }\end{array}$ & $4,711^{*}$ \\
\hline 13 & Kualitas layanan & $-1,642$ \\
\hline 14 & $\begin{array}{l}\text { Tingkat } \\
\text { pengetahuan }\end{array}$ & $2,899 *$ \\
\hline 15 & Tingkat kreatifitas & 1,312 \\
\hline 16 & Tingkat kerjasama & 1,404 \\
\hline 17 & Dukungan keluarga & $2,867^{*}$ \\
\hline 18 & $\begin{array}{l}\text { Dukungan } \\
\text { kelompok }\end{array}$ & $2,483 *$ \\
\hline 19 & $\begin{array}{l}\text { Dukungan sarana } \\
\text { prasarana }\end{array}$ & $2,370 *$ \\
\hline 20 & Dukungan pasar & $3,795^{*}$ \\
\hline
\end{tabular}

Keterangan : *nyata pada $\alpha<0,05$;

No. 1-6: karakteristik individu;

No. 7-11: karakteristik inovasi;

No. 12-16: kinerja fasilitator;

No. 13-20: dukungan eksternal

lebih cenderung menanam tanaman yang diperoleh dengan cara membeli sarana produksi yang unggul dan berkualitas, sehingga jenis tanamannya kurang bervariasi. Menurut Suyastiri (2008) rumah tangga yang memiliki pendapatan tinggi cenderung untuk mengkonsumsi pangan yang bervariasi dan meningkatkan kualitas pangannya dengan cara membeli bahan pangan yang nilai gizinya lebih tinggi.

Uji signifikansi pengaruh peubah bebas sifat/karakteristik inovasi menunjukkan bahwa indikator karakteristik inovasi yang berpengaruh terhadap keberlanjutan adopsi adalah keuntungan relatif $\left(\mathrm{t}_{\text {hit }} 2,41>1,96\right)$, tingkat kesesuaian teknologi $\left(\mathrm{t}_{\text {hit }} 2,30>1,96\right)$ dan tingkat kerumitan teknologi untuk diadopsi oleh wanita tani $\left(\mathrm{t}_{\text {hit }}-3,52>1,96\right)$; nilai negatif tingkat kerumitan menunjukkan bahwa tidak rumitnya inovasi teknologi, maka akan semakin mudah teknologi untuk diadopsi. Tingkat keuntungan dan tingkat kesesuaian merupakan aspek utama sifat inovasi yang harus diperhatikan dalam pengembangan pengelolaan pekarangan. Selama inovasi teknologi pengelolaan pekarangan tidak membutuhkan banyak biaya (efiseinsi biaya), mendapatkan tambahan pendapatan, sesuai dengan waktu wanita tani dan mempunyai kesesuaian dengan kondisi budaya setempat maka keberlanjutan adopsi inovasi pengelolaan pekarangan dapat terus dipertahankan.

Tabel 6 juga menunjukkan bahwa terdapat hubungan nyata antara kinerja fasilitator dalam melakukan kunjungan $\left(\mathrm{t}_{\mathrm{hit}} 4,71>1,96\right)$ dan tingkat pengetahuan fasilitator $\left(t_{\text {hit }} 2,90>1,96\right)$ dengan keberlanjutan adopsi pengelolaan pekarangan. Semakin sering fasilitator mengunjungi wanita tani maka keberlanjutan pengelolaan pekarangan akan terus berlanjut. Wanita tani dalam pengelolaan pekarangan masih perlu terus mendapatkan bimbingan di lapangan terutama dalam hal introduksi inovasi baru. Dengan dikunjunginya secara berlanjut, maka akan menghilangkan tingkat kejenuhan wanita tani dalam mengelola pekarangan karena adanya ide baru dari fasilitator dan tempat mengadu permasalahan yang dihadapi. Ide baru (inovasi) dan solusi pemecahan masalah terkait dengan tingkat pengetahuan fasilitator. Semakin tinggi tingkat pengetahuan fasilitator maka keberlanjutan adopsi pengelolaan pekarangan akan terus berlanjut karena inovasi akan terus berkelanjutan. Semakin sering wanita tani berhubungan dengan fasilitator maka keberlanjutan pengelolaan pekarangan akan tetap terjaga (berkesinambungan).

Hasil analisis berganda peubah dukungan eksternal terhadap keberlanjutan pengelolaan lahan pekarangan menunjukkan bahwa semua dukungan eksternal yang dianalsis mempengaruhi secara nyata peubah terikat keberlanjutan. Indikator peubah dukungan eksternal yang mempengaruhi secara nyata keberlanjutan secara berurutan adalah dukungan pemasaran $\left(\mathrm{t}_{\mathrm{hit}} 3,79>1,96\right)$, dukungan keluarga $\left(\mathrm{t}_{\text {hit }} 2,87>1,96\right)$, dukungan kelompok 
$\left(\mathrm{t}_{\text {hit }} 2,49>1,96\right)$ dan terakhir dukungan sarana prasarana $\left(\mathrm{t}_{\mathrm{hit}} 2,37>1,96\right)$.

Hal utama peubah dukungan eksternal yang berpengaruh nyata terhadap keberlanjutan adalah pemasaran. Selama ini, responden mengandalkan kelompokdanusahasendiri(masing-masingindividu) dalam memasarkan hasil produk pekarangan. Mereka mengalami kesulitan, karena mereka harus mencari sendiri konsumen yang bersedia menampung hasil produk mereka. Pengelolaan pekarangan akan terus berlanjut/ berkembang jika produk hasil usaha lahan pekarangan dapat dengan mudah dijual. Selama ini, wanita tani hanya mengandalkan kelompok dalam memasarkan hasil produk usaha lahan pekarangannya, kelompok menjembatani pemasaran produk hasil usaha pekarangan. Seperti halnya di Kecamatan Jalaksana kelompok berperan dalam menampung hasil, membeli dan memjembatani dengan pihak konsumen.

Dukungan sarana prasarana usaha lahan pekarangan utamanya ketersediaan sarana produksi terhadap tujuan pengelolaan pekarangan memiliki pengaruh nyata yang positif terhadap keberlanjutan pengelolaan lahan pekarangan. Hal ini menunjukkan bahwa ketersediaan sarana prasarana usahatani mempermudah responden dalam menjalankan usaha lahan pekarangan. Responden dapat dengan mudah mewujudkan usahanya untuk mengelola lahan pekarangan, namun jika terdapat kesulitan dalam sarana prasarana maka kegiatan usaha lahan pekarangan akan sulit berkembang/berkelanjutan.

Selama ini, khususnya wanita tani di kedua lokasi penelitian pemenuhan sarana produksi dilakukan dengan cara membeli, memanfaatkan sumberdaya yang ada di lingkungan tempat tinggal, serta saling meminta, bertukar, meminjam bibit/ benih, pupuk, peralatan tanaman kepada anggota dan kelompok wanita tani lainnya. Berdasarkan hasil diskusi dengan beberapa wanita tani, diperoleh informasi bahwa yang terpenting dalam hal dukungan sarana prasarana adalah persoalan mudah atau tidaknya memperoleh sarana dan kualitas sarana produksi yang dibutuhkan. Ada satu hal yang dirasakan memberatkan wanita tani dalam pemenuhan kebutuhan sarana produksi, di mana mereka harus meluangkan waktu untuk membelinya, dan sebagian lainnya tidak terbiasa jika mereka berurusan dengan kios pupuk atau distribusi formulator sarana produksi. Dalam hal ini, mereka mengandalkan suami yang bekerja sebagai petani, namun bagi sebagian lainnya, wanita tani mengandalkan kelompok dalam pemenuhan kebutuhan sarana produksi atau membeli sarana produksi di kios-kios pertanian di pusat kecamatan. Pada intinya, semakin tersedia dan mudahnya memperoleh sarana prasarana usaha lahan pekarangan maka keberlanjutan adopsi teknologi pengelolaan pekarangan akan terus dapat dilaksanakan.

\section{Kesimpulan}

Tingkat keberlanjutan adopsi inovasi pengelolaan pekarangan secara berurutan ditunjukkan dengan keberlanjutan ekonomi, keberlanjutan produksi dan keberlanjutan kemitraan. Hasil analisis regresi linear berganda Uji t (parsial), secara berurutan indikator peubah karakteristik individu yang berpengaruh nyata adalah umur, motivasi, jumlah anggota keluarga, tingkat pendidikan, curahan waktu wanita tani dan pendapatan keluarga. Indikator karakteristik inovasi yang berpengaruh nyata yaitu keuntungan relatif dan tingkat kesesuaian inovasi. Indikator kinerja fasilitator yang berpengaruh adalah tingkat kunjungan dan tingkat pengetahuan. Semua indikator dukungan eksternal pemasaran, dukungan keluarga, dukungan kelompok dan dukungan sarana prasarana berpengaruh nyata terhadap keberlanjutan pengelolaan pekarangan.

\section{Daftar Pustaka}

Badan Ketahanan Pangan (BKP). 2010. Perkembangan Situasi Konsumsi Penduduk di Indonesia.

Ho Maewan dan Ching Lim Li. 2006. Gerakan Menuju Dunia Berkelanjutan Bebas dari Rekayasa Genetik. n.p: Independent Science Panel.

Indrianingsih KS. 2010. Penyuluhan pada Petani Lahan Marjinal: Kasus Adopsi Inovasi Usahatani Terpadu Lahan Kering di Kabupaten Cianjur dan Kabupaten Garut Provinsi Jawa Barat [disertasi]. Bogor (ID): Institut Pertanian Bogor.

Mardiharini M. 2011. Model Kawasan Rumah Pangan Lestari dan Pengembangnnya ke Seluruh Provinsi di Indonesia. Warta Penelitian dan Pengembangan Pertanian. 33(6):3-5. Badan Penelitian dan Pengembangan Pertanian. 
Mugniesyah Siti. 2006. Materi Bahan Ajar: "Ilmu Penyuluhan (KPM 211)".Bogor: Departemen Sains Komunikasi dan Pengembangan Masyarakat, Institut Pertanian Bogor.

Purnaningsih N, Sugihen BG, Slamet M, Saefuddin A, Padmowiharjo S. 2006. Faktor-faktor yang Mempengaruhi Adopsi Inovasi Pola Kemitraan Agribisnis Sayuran di Jawa Barat. Jurnal Penyuluhan. 2(2).

Rogers EM. 2003. Diffusion of Innovations. Fifth Edition. A Division of Simon \& Schuster, Inc. 1230 Avenue of The Americas New York (US): The Free Press.
Soekartawi. 1988. Prinsip Dasar Komunikasi Pertanian. Jakarta (ID):Universitas Indonesia Press.

Suratiyah K. 2003. Usahatani. Diktat. Diterbitkan untuk Kalangan Sendiri. Program Studi Agribisnis. Yogyakarta (ID): Jurusan Sosial Ekonomi Pertanian Fakultas Pertanian UGM.

Suyastiri NM. 2008. Diversifikasi Konsumsi Pangan Pokok Berbasis Potensi Lokal Dalam Mewujdukan Ketahanan Pangan Rumah Tangga Pedesaan. Jurnal Ekonomi Pembangunan, 13 (1):51-60. [internet]. [dapat diunduh di: http:// journal.uii.ac.id]. 